\title{
Code of Language Corruptors in the Corruption Court in the Forensic Linguistic Approach
}

\author{
Sabriandi Erdian ${ }^{1}$, T. Silvana Sinar ${ }^{2}$, Susanto $^{3}$, T. Syarfina ${ }^{4}$ \\ \{sabriandierdian@students.usu.ac.id ${ }^{1}$,tengkusilvana@usu.ac.id², susanto@ubl.ac.id³ \\ tengku_fina@yahoo.co.id ${ }^{4}$ \} \\ ${ }^{1,2}$ Universitas Sumatera Utara, Medan, Indonesia. \\ ${ }^{3}$ Bandar Lampung University, Bandar Lampung, Indonesia \\ ${ }^{4}$ Head of Learning Division, Language and Book Development Agency, Jakarta, Indonesia
}

\begin{abstract}
The modus operandi of corruptors in conducting corrupt acts uses codes as a tool to fool people around them. The cipher language they use develops according to the technological advances they use in carrying out the action. The cipher language is found in open court trials of corruption from witness statements, suspects in answering questions from judges, prosecutors and legal counsel. Cipher language research used by corruptors uses the forensic linguistic approach as a study of language in the realm of law. This research uses descriptive and qualitative observational method. The purpose of this study is to find the codes used by corruptors in carrying out corrupt practices. The benefits of this research as a contribution to the community in order not to commit acts of corruption. The references used in this study are Gibbons 2003, Gerald R. McMenamin 2002, Malcolm Coulthard and Alison Johnson 2007.
\end{abstract}

Keywords: Coding, Corruption, Forensic Linguistics and Open Trials.

\section{Introduction}

The arrest of a person or group of people in a gratuity act by the Corruption Eradication Commission (hereinafter written by the KPK) and covered by the print media, online newspapers, television and also radio makes news very embarrassing. The arresting operation carried out by the KPK is the vision and mission of the KPK in eradicating corruption in Indonesia. This is in accordance with the Law of the Republic of Indonesia Number 31 of 1999, Law of the Republic of Indonesia Number 30 of 2002. The vision and mission of the Corruption Eradication Commission in accordance with the 2017 strategic plan is to join together with elements of the nation to realize an Indonesia that is clean of corruption and increase efficiency and effectiveness and decrease the level of corruption in Indonesia through coordination, supervision, monitoring, prevention, and enforcement with the participation of all elements of the nation.

[1, pp. 100] in his paper entitled "Corruption Eradication Strategy" states a study conducted by Transparency International Indonesia shows that corrupt practices can be identified including: (1) manipulation of state money; (2) bribery and extortion practices; (3) money politics; and (4) business collusion. [2, pp. 61] in his book The Strategy to Eradicate Corruption states that corruption is carried out in secret because there is a shared interest among the perpetrators. To maintain the confidentiality of these corrupt practices, corruptors use the codes they agree to communicate. However, as the saying goes by cleverly storing the carcasses finally smelled, as well as the secrecy of corrupt acts that were covered tightly with 
the code was revealed and the results of the KPK, and the perpetrators of corruption were arrested for abusing their authority and power.

The realization of the arrest operation carried out by the Corruption Eradication Commission cannot be separated from the role of national elements, to reduce corrupt acts carried out by individuals or groups that misappropriate state assets by utilizing their power as state apparatus in developing the nation and state of Indonesia in accordance with the opening of the 1945 Constitution, Law-Basic grounds of 1945, GBHN and Pancasila. Likewise, the private sector that is looking for profits in running its business and establish cooperation in development that is not in accordance with the agreement in carrying out development. After the arrest operation carried out by the KPK and the process of investigation, investigation, then the file is submitted to the corruptor act of corruption to determine the legal status of the person or group. In a scheduled open hearing, a person or group is presented to provide information in the trial in accordance with the needs of the court clerk.

The presence of a person or group (hereinafter temporarily referred to as: the suspect) uses Indonesian language or also uses local language as the purpose of speaking in court. The use of spoken and written languages that use codes in language when carrying out the action is carried out an analysis to find the language patterns they use. While in court proceedings, research can be conducted to find out how to communicate with judges, prosecutors, lawyers, witnesses, and defendants [3]. This research will make a characteristic in the language when carrying out the action for their interests and they understand each other in the use of codes. To break the code that they used in acts of corruption requires a strategic secret to the KPK so that other candidates do not dare to commit acts of corruption in the Unitary State of the Republic of Indonesia. To improve the performance of the KPK, Head of the State Code Institute Djoko Setiadi met with the Chair of the KPK to share about technological advances, cyber space including wiretapping. This is done to synergize the spirit of inter-agency in the prevention and eradication of corruptor acts of corruption in Indonesia [4].

\section{Corruptor Language Codes}

Solve a problem using a code as a solution. The code used is usually not free from daily habits, ranging from the date, month, year, personal ownership, to the names related to him. Likewise, in carrying out acts of corruption that use general and specific terms, so that corrupt codes committed by corruptors can be examined using micro and macro linguistic studies. Thanking Sabir Laluhu for publishing a book on the Metamorphosis of Corruption Communication Codes, first in Indonesia, which analyzed corruption in terms of communication science and hopes to further develop it with a new study, forensic communication against corruption.

[5] says the code metamorphosis of corruption communication is resolved using language and forensics. Characteristics of corruption are generally still visible, which involves not only one person, using codes in communication, and using cash to make transactions, [6, pp. 5]. [7] in his paper "Functional Markers in Corruption Cases" states, semiotic codes, symbols or codes used in corrupt communication have context and reality.

These facts are not only physical in nature such as the human body, organs, blood, clothing, weapons, bullets, shells, knives, identification marks, the natural environment, but also wider "facts", such as language, sound, writing, symbols, codes, internet sites, or overall "cultural facts" related to crime, according to [8]

Proving the codes in corruption cases which until now has become a priority because the language has become a culture and continues to grow in accordance with the era. The 
emergence of a secret language used by corruptors is not new because since time immemorial the codes have been used by the community for a certain purpose. Cases of corruption are uncovered and entered the trial process on average in code. Special expertise for judges and law enforcement to uncover what is behind the secret language according to [9, pp. 15] Furthermore, Julijanto mentioned that every code language is always the key. Therefore, law enforcers must understand the language play of corruption and the rules of its formation.

The sophistication of technology in the current era is so fast developing with a variety of applications that are found teknorat to meet market needs, from conventional models to modern ones. Like now there is a faceapp application that can change the style of self, old to young or vice versa. From this, experts are needed in their respective fields in handling corruption cases to solve various modes and operandi committed by corruptors. The code that is used by corruptors are as follows.

Table 1. A Collection of codes corruption

\begin{tabular}{|c|c|c|}
\hline $\begin{array}{l}\text { Indonesia } \\
\text { Language }\end{array}$ & $\begin{array}{l}\text { English } \\
\text { Language }\end{array}$ & Information \\
\hline $\begin{array}{l}\text { Kilo, apel Malang, apel } \\
\text { Washington, semangka, } \\
\text { pelumas, ketuabesar, big boss, } \\
\text { sibali, babe, lucky,iwan. }\end{array}$ & $\begin{array}{l}\text { Kilo, Malang apple, } \\
\text { Washington apple, } \\
\text { watermelon, lubricant, big } \\
\text { chairman, big boss, bali, } \\
\text { babe, lucky, iwan. }\end{array}$ & \multirow[t]{8}{*}{$\begin{array}{l}\text { Metamorphosis } \\
\text { Communication Codes }\end{array}$} \\
\hline $\begin{array}{l}\text { Titipan, bungkusan, pesanan, } \\
\text { barang, sesuatu, bingkisan, } \\
\text { kg/gram, rezeki,timgegana. }\end{array}$ & $\begin{array}{l}\text { Courier, parcel, orders, items, } \\
\text { things, gifts, kg / gram, } \\
\text { sustenance, Gegana team }\end{array}$ & \\
\hline $\begin{array}{l}\text { Santri, imam, kiai, pengajian, } \\
\text { murtad, panglima. }\end{array}$ & $\begin{array}{l}\text { Santri, Priest, kiai, recitation, } \\
\text { apostate, commander. }\end{array}$ & \\
\hline $\begin{array}{l}\text { Sapibesar, sapi kecil, uang } \\
\text { lelah, ketemu darat, uang } \\
\text { gondrong, uang jenggot, } \\
\text { batangan, kilo. }\end{array}$ & $\begin{array}{l}\text { Big cattle, small cows, tired } \\
\text { money, meet land, longish } \\
\text { money, beard money, bars, } \\
\text { kilos. }\end{array}$ & \\
\hline Kilogram, pahlawan, spare part. & $\begin{array}{l}\text { Kilograms, heroes, spare } \\
\text { parts. }\end{array}$ & \\
\hline $\begin{array}{l}\text { Roti, ikat, resep, pasien, obat, } \\
\text { butir, pembuat resep, rumah } \\
\text { sakit, peluru. }\end{array}$ & $\begin{array}{l}\text { Bread, bunch, recipe, patient, } \\
\text { medicine, item, recipe maker, } \\
\text { hospital, bullet. }\end{array}$ & \\
\hline $\begin{array}{l}\text { Kue, barang, Singapura, kilo, } \\
\text { ledakan, kedipan, apelamerika, } \\
\text { suntikan, peluru, biru, merah, } \\
\text { hijau, kuning, utang, sepukul, } \\
\text { titipan, paket, bingkisan, } \\
\text { bukagendang, tutupgendang, p; } \\
\text { a; s. }\end{array}$ & $\begin{array}{l}\text { Cakes, goods, Singapore, } \\
\text { kilos, explosions, winks, } \\
\text { American apples, injections, } \\
\text { bullets, blue, red, green, } \\
\text { yellow, debt, o'clock, deposit, } \\
\text { packages, parcels, open } \\
\text { drums, drums, p; a; s. }\end{array}$ & \\
\hline $\begin{array}{l}\text { Ana, ustadz besar, ustadz kecil, } \\
\text { the white hair man (uban), } \\
\text { engkong, bunda putri, bunda, }\end{array}$ & $\begin{array}{l}\text { Ana, large ustaz, small } \\
\text { ustadz, the white hair men } \\
\text { (gray hair), ankles, mothers }\end{array}$ & \\
\hline
\end{tabular}




\begin{tabular}{|c|c|}
\hline $\begin{array}{l}\text { annukudarbainmilyar, (arab), } \\
\text { putih, buku, daging, fustun } \\
\text { (arab), karattasak (4ashingt) } \\
\text { atau kertas biasa. }\end{array}$ & $\begin{array}{l}\text { of mothers, mothers, } \\
\text { annukudarbain billion, } \\
\text { (arabic), white, books, meat, } \\
\text { fustun (arabic), karattasak } \\
\text { (ashingt) or plain paper. }\end{array}$ \\
\hline $\begin{array}{l}\text { Masuk 4ashin, (me-) \& (di-) } \\
\text { bom, si tikus, kue, resep, } \\
\text { vitamin, kristalin, big boss, } \\
\text { support, oleh-oleh tipis, ade, } \\
\text { kakak. }\end{array}$ & $\begin{array}{l}\text { Enter ashin, (me) \& (di-) } \\
\text { bomb, the mouse, cake, } \\
\text { recipe, vitamins, crystalline, } \\
\text { big boss, support, thin } \\
\text { souvenirs, ade, brother. }\end{array}$ \\
\hline $\begin{array}{l}\text { Wisanggeni, jahitan, baju, } \\
\text { penjahit, kahyangan, bom, } \\
\text { bahan kain, took. }\end{array}$ & $\begin{array}{l}\text { Wisanggeni, stitches, clothes, } \\
\text { tailors, heaven, bombs, fabric, } \\
\text { shops. }\end{array}$ \\
\hline $\begin{array}{l}\text { Titipan, buku, pabrik, cetakan, } \\
\text { meter, baterai, ijazah, } \\
\text { komandan nekat, satu pintu, m ; } \\
\mathrm{k} \text { (huruf), susu atas, sunah } \\
\text { rasul. }\end{array}$ & 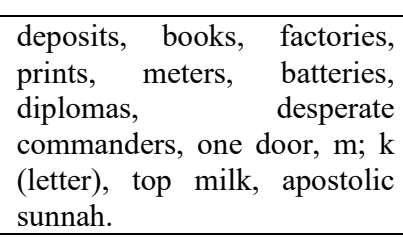 \\
\hline Pinang, ton, pace (papua). & $\begin{array}{l}\text { Areca nuts, tons, pace } \\
\text { (Papua) }\end{array}$ \\
\hline $\begin{array}{l}\text { Babe,bos besar, pak pendek, } \\
\text { pak gendut, bibit pohon, bibit } \\
\text { tanaman, titipan, taman, } \\
\text { ditanam, meter, pohon } \\
\text { setinggi, dua meter, cluster, } \\
\text { batang bibit }\end{array}$ & $\begin{array}{l}\text { Babe, big boss, short pack, fat } \\
\text { pack, tree seedlings, plant } \\
\text { seeds, safekeeping, garden, } \\
\text { planted, meters, tall trees, two } \\
\text { meters tall, clusters, seedling } \\
\text { trunks }\end{array}$ \\
\hline $\begin{array}{l}\text { Nomor sepatu, ukurkan, atuk, } \\
\text { oleh-oleh, kacang pukul, uang } \\
\text { rokok...mangido500 rang } \\
\text { boanon... (batak). }\end{array}$ & $\begin{array}{l}\text { Shoe number, size, souvenir, } \\
\text { souvenir, hit bean, cigarette } \\
\text { money ... mangido } 500 \text { rang } \\
\text { boanon ... (hobo). }\end{array}$ \\
\hline $\begin{array}{l}\text { Emas, } 3 \text { ton, apel Washington, } \\
\text { barang, } 1 \text { ekor, titipan, biaya, } \\
\text { transportasi dan alat berat, } \\
\text { pembayaran bibit kelapa sawit, } \\
\text { dpbatubara, pembelian alat, } \\
\text { perkebunan, tagihan, im\&nov, } \\
\text { komunikasi darat, kiai, pempek, } \\
\text { ayuk, ikan asin, sintua } \\
\text { (dayak/4ashin), bos besar, bang } \\
\text { budi, angkutan batubara. }\end{array}$ & $\begin{array}{l}\text { Gold, } 3 \text { tons, Washington } \\
\text { apples, goods, 1 tail, deposit, } \\
\text { fees, transportation and heavy } \\
\text { equipment, payment of palm } \\
\text { oil seedlings, dp coal, } \\
\text { equipment purchases, } \\
\text { plantations, bills, im\&nov, } \\
\text { land communication, kiai, } \\
\text { pempek, ayuk, salted fish, } \\
\text { sintua (dayak / ashin), big } \\
\text { boss, budi, coal } \\
\text { transportation. }\end{array}$ \\
\hline $\begin{array}{l}\text { Air atau air minum, sembako, } \\
\text { barang, titipan, setoran, kiai. }\end{array}$ & $\begin{array}{l}\text { Water or drinking water, } \\
\text { groceries, goods, deposits, } \\
\text { deposits, kiai. }\end{array}$ \\
\hline $\begin{array}{l}\text { Buku, kakor, titipan, jokosusilo, } \\
\text { sintua, kiai, Palembang, dana } \\
\text { taktis, spanduk. }\end{array}$ & $\begin{array}{l}\text { Books, kakor, safekeeping, } \\
\text { jokosusilo, sintua, kiai, } \\
\text { Palembang, tactical funds, } \\
\text { banners. }\end{array}$ \\
\hline
\end{tabular}




\begin{tabular}{|c|c|c|}
\hline $\begin{array}{l}\text { Buku, sigendut, yang tengah, } \\
\text { gb/bundar/ gedung bundar, } \\
\text { titipan, stadium 4, jebakan } \\
\text { Batman, orang penting di } \\
\text { sumut, lulus, biaya, konsultasi, } \\
\text { pakuban, uang kopi-kopi, } \\
\text { arisan, uangketok. }\end{array}$ & $\begin{array}{l}\text { Book, fat, middle, gb / round } \\
\text { / round building, entrusted, } \\
\text { stage 4, Batman trap, } \\
\text { important person in North } \\
\text { Sumatra, pass, fees, } \\
\text { consultation, pack gray, } \\
\text { coffee money, social } \\
\text { gathering, knock money. }\end{array}$ & \\
\hline $\begin{array}{l}\text { Angka (misalnya } \\
\text { sesuaiperolehansuara di pemilu } \\
2014 \text {, angka dan huruf } \\
\text { (misalnya 1-e dan 2-d), huruf } \\
\text { "p"huruf "p" danangka } \\
\text { (misalnya p2 dan p4), ban } \\
\text { berjalan satu pintu, uang kopi, } \\
\text { baju jahitan (9) sisetan. }\end{array}$ & $\begin{array}{l}\text { Numbers (for example 1) } \\
\text { according to votes in the 2014 } \\
\text { election, numbers and letters } \\
\text { (for example 1-e and 2-d), the } \\
\text { letter "p" the letter "p" and } \\
\text { numbers (for example p2 and } \\
\text { p4), one-door conveyor belt, } \\
\text { coffee money, stitches (9) the } \\
\text { devil. }\end{array}$ & \\
\hline $\begin{array}{l}\text { Malaikat penolong, pihak yang } \\
\text { membantu, dokter, tape, } \\
\text { sangu/oleh-oleh, bungkus besar, } \\
\text { bungkus kecil, pakbos, nomor } \\
\text { sepatu, ukuran baju, algojo, } \\
\text { suku. }\end{array}$ & $\begin{array}{l}\text { Helper angels, assistants, } \\
\text { doctors, tape, sangu / } \\
\text { souvenirs, large wrappers, } \\
\text { small wrappers, boss packs, } \\
\text { shoe numbers, dress sizes, } \\
\text { executioners, tribes. }\end{array}$ & \\
\hline $\begin{array}{l}\text { Kue, barang, isitas, titipan, } \\
\text { keranjang, taukedde+, sibos, } \\
\text { harco, 5ashidua, si sepuluh atau } \\
\text { lantai } 10 \text { pdip, central park. }\end{array}$ & $\begin{array}{l}\text { Cake, goods, bag contents, } \\
\text { deposit, basket, taukedde }+ \text {, } \\
\text { the boss, harco, ashidua, tenth } \\
\text { or 10th floor pdip, central } \\
\text { park. }\end{array}$ & \\
\hline $\begin{array}{l}\text { Dana operasional, paketan, } 2 \\
\text { meter, cetakan undangan, obat, } \\
\text { kacang pukul, ekor, ton mas, } \\
\text { ustad, pesantren dan kiyai, apel } \\
\text { Malang, apel Washington, dan } \\
\text { salak Bali. }\end{array}$ & $\begin{array}{l}\text { operational funds, packages, } \\
2 \text { meters, invitation prints, } \\
\text { medicine, hit beans, tails, tons } \\
\text { of goldfish, religious } \\
\text { teachers, pesantren and kiyai, } \\
\text { Malang apples, Washington } \\
\text { apples, and balisalak. }\end{array}$ & $\begin{array}{l}10 \text { Codes and Codes in Corruption } \\
\text { Cases }[10]\end{array}$ \\
\hline $\begin{array}{l}\text { '1 Ton', 'Tina Toon', 'Ahok', } \\
\text { 'Apel Malang' dan 'Apel } \\
\text { Washington', 'Pelumas' dan } \\
\text { 'Semangka', 'Pengajian', 'Santri' } \\
\text { dan 'Anak Jin', 'Mcguire', } \\
\text { 'Chivas Regal' dan 'Vodka', } \\
\text { 'Undangan', 'Buku' dan } \\
\text { 'Perhatian', 'Undangan' (Suap } \\
\text { DPRD Jambi), 'Sapi' dan } \\
\text { 'Kambing', rKalender', } \\
\text { 'TelurAsin', 'Sarung', } \\
\text { 'KacangPukul', 'Obat', 'Bibit' } \\
\text { dan 'BatangTanaman', 'Ton } \\
\text { Pinang' Dan 'Ton Emas'. }\end{array}$ & $\begin{array}{l}\text { Tons of, Tina Toon, Ahok, } \\
\text { Apple Malang, Apple } \\
\text { Washington, Recitation, A } \\
\text { lubricant and watermelon, } \\
\text { Santri and son of Jin, } \\
\text { Mcguire, Chivas regal and } \\
\text { vodka, invitation card, Books } \\
\text { and attention, invitation card, } \\
\text { A bribe parliament jambi, } \\
\text { Cow and Goat, Calendar, } \\
\text { Salted egg, Sarong, Hit the } \\
\text { Beans, Drug, Plant Seeds and } \\
\text { Stems, Tons of betel nuts and } \\
\text { tons of gold. }\end{array}$ & $\begin{array}{l}\text { The Code for Corruptors Has } \\
\text { Turned Into a Trend [11] }\end{array}$ \\
\hline Ujian & Exam & $\begin{array}{l}\text { KPK Identifies the Use of Exam } \\
\text { Codes in the Jepara Regent's }\end{array}$ \\
\hline
\end{tabular}




\begin{tabular}{|l|l|l|}
\hline & & Bribery Case [12] \\
\hline Pohon dan Ratu Kecantikan & Trees and Beauty & $\begin{array}{l}\text { [Code 'Tree' and 'Beauty Queen' in } \\
\text { Medan Bribery Judge Bribery [13] }\end{array}$ \\
\hline Keju & Cheese & $\begin{array}{l}\text { [KPK Reveals Cheese Code in } \\
\text { Bribery Case of Central Lampung } \\
\text { Regent [14] }\end{array}$ \\
\hline
\end{tabular}

The codes above used by corruptors are revealed in an open trial in a corruption court. The variety of codes that they use in carrying out their actions is becoming a trend and popular, so that there are social media users who neutralize with symbols in social status as embittered at the behavior of the corruptors, let alone the media and the public have seen corruptors who have been imprisoned just doing actions vacation they should be in a correctional institution. This makes the code what else will they do with them outside the prison for reasons of treatment?

The greater of secret that is hidden in the act of corruption then stronger the desire of a person or group to commit acts of corruption to comply with the wishes. In their paper [15, pp. 434] that desire (need) has a closeness to the GONE theory associated with psychology that the causes of corruption consist of four causes, namely Greed (greed), Opportunity (opportunity), Need (Need) and Exppsures (light punishment).

Humans continue to work with dreams and all the ways that humans do to realize these dreams. But if in realizing that dream justifies all means as corruptors do, it will be a bad precedent in the wheel of government. This is evident that those who commit acts of corruption are people who sit in government as governors, regents, mayors, judges, prosecutors, members of the council and others who have harmed the state money for himself and his cronies. This proverb gives a message to us all to be a lesson and learning in life "Abite nummi, ego vos mergam, ne mergar a vobis" (go o money, I will drown you, so you can't drown me), [16], [17]. Back again to the message and socialization of the government, the private sector and also the public that corruption is a common enemy that can threaten the future of the Indonesian nation. As an enemy, it is natural that corruption must always be fought and eradicated by its roots, [18, pp. 174].

\section{Definition Of Codes And Relations In LANGuage}

According to the [19: pp. 1259] that secret chiper; code. In English, the proper term to use as an equivalent to the word encoding, is cryptography 'cryptography'. Cryptography comes from the Greek word kryptós which means secret 'secret', and gráphein which means writing 'writing'. So, cryptography means secret writing 'secret writing' [20: pp. 216]. Whereas according to the epistemology the code is as first noted by Gumperz in 1982, when "a message in one code is repeated in the other code...such repetitions may... amplify or emphasize the message", [21: pp. 156].

Ciphers used in letters and numbers have meaning and significance of its users to the goal with the initial agreement. Relationship code in language can be known through the message it conveys from the beginning to the end of language use. According to [22: pp. 126] in his paper "The Cryptos Language of Corruptors" in Indonesia meant the secret language used by someone in corrupting public money. Furthermore [22: pp. 115] mentions the cryptos language used to conceal, hide, and obscure the meaning of words from actual words.

The power of language to transcend space and time for people who use language as a language of interest. The use of spoken and written language are performed on them in a 
dream to use the codes as a destination to perform acts of corruption will be futile. Languages have strength in body and soul that what is uttered will be a witness in life and this will be something that can be accounted for. By knowing the meanings and meanings in the language used, each utterance has its own purpose and function.

We can see when a newborn child gives a message through his tears and so does when death picks him up. When you get the mandate to occupy a position and power, then use the mandate as well as possible and do not ever betray because if you betray the trust by committing acts of corruption, death will pick him up.

\section{FORENSIC LingUiSTIC APPROACH}

Language is a communication system. In this broad sense, human language is a code that communicates meaning, as do other types of communication systems such as animal sounds and movements, morse point and line codes, traffic signs and traffic lights, human movements and body language, and even source codes computer, [23: pp. 23].

The rapid growth of science and knowledge in the digital era makes human needs continue to evolve the science which studies. Likewise, linguistics experiences an approach with other scientific disciplines and is born into a new approach, namely forensic linguistics. The birth of forensic linguistics has a long process and has its own scope in analyzing it.

Forensic linguistic studies have a focal point and include several issues including (1) the language of legal documents, (2) the language of the police and law enforcers, (3) interviews with children and witnesses who are vulnerable in the legal system, (4) interactions in the courtroom, (5) linguistic evidence and expert testimony in courtroom, (6) authorship and plagiarism, and (7) forensic phonetics and speaker identification, [24]

Matters reviewed in forensic linguistics include: 1) analysis of the use of language in the realm of law; 2) investigation of the deepest elements in the use of language, which can further be used as evidence in legal proceedings; and 3) examine the use of the language of law enforcement officials in the judicial process, both investigations and trials, [25: pp. 38]. The entire legal process throughout the world involves many "experts" and "non-experts", as Agar in 1985 and Mayr in 2008 said in [26: pp. 9].

One's expertise can be seen from flying hours in resolving problems at trial by proving a certificate as a supporter of his expertise, because what he solves is related to the issue of human rights and responsibilities in the world. If he is right in his actions, then uphold the truth to the highest and vice versa if he is lying, then punish for his lies regardless of who he is and what background he is. Moreover, his case regarding corruption that distorts his position and power at the expense of state money and also the right of the people's survival today and beyond.

Forensic linguistics as a new paradigm in science provides an approach in terms of language and became popular after giving understanding in the use of spoken and written language, be it academically, trial and also for other interdisciplinary. The relationship between law and forensic linguistics tightened in any transactions in accordance with the objectives, benefits and usefulness in upholding truth and justice. This is according to [27] says language and laws are interrelated, mutual influence, even regarded as the embodiment of society and culture, which in turn, may be affected either by language or by law.

[3] in their paper "Dimensions of Language Analysis in Forensic Linguistic Studies" consists of two kinds, namely oral language and written language, then the field of forensic linguistic studies consists of: (1) language studies in the legal process, (2) language studies in 
legal products, and (3) language studies in legal evidence. The results of his research to explain aspects of the typical dimensions of language analysis in forensic linguistics is comparable dimensions, distinctive, and measuring expected to contribute insights to the development of forensic linguistics studies.

The existence of forensic linguistics in Indonesia provides a new vehicle for higher education, so that theory and practice have responsibilities in social, cultural, legal, economic, political and other scientific disciplines, both in academia and in society. The development of forensic linguistics has become a trend in academia and society in Indonesia in general and North Sumatra in particular.

\section{Methods And Data Analysis}

The research method ciphers corrupt language is made to find a pattern of language used by corruptors. The use of the code language they use has a character in pronunciation and also in writing. The language they use through a short message can be known through signs and markers every word, sentence and the meaning they write. There are times when the linguists required to provide proof of the special vocabulary, possibly drug-coded words, which occur in speech that is not burdensome. [28: pp. 294-295] ; [24].

Method study conducted in open court in corruption court in Medan by taking the primary data from the trial and continued dialogue mentranskripkan trial from beginning to end of the trial with the number 10 (ten) times of trial. All primary data are identified, analyzed and concluded according to the findings of the study. [29] "listening method" or "listening" is done by listening, namely listening to the use of language. In qualitative data analysis, [30] states, namely: (1) analyzing the process of the occurrence of a social phenomenon and obtaining a complete picture of the process; and (2) analyze the meaning behind the information, data and process of a social phenomenon.

The codes are made to give the impression that the codes have meaning contained corrupt according to the agreement and followed in accordance with the instructions, to avoid misunderstandings on the meaning of each sentence uttered by the speaker to the hearer. An open trial at the Corruption Court in Medan in the case of abuse of power and position was found as a code in the witness statement. As for the conversation and analysis below:

Prosecutor: The witness told Ayen that he would buy a car. Does it mean that 1 billion of money will indeed be used to buy a car or what?

Witness : The code of Mr. Mulia is actually KW Mr. Mulia's obligation.

Prosecutor: The code, which gave rise to or created the code, was this a witness or did it have been fabricated before? Already agreed or what, how come, it can be like a tit for tat, right?

Witness : Mr.Ayen who appeared, Mr. Prosecutor.

Prosecutor: Pak Ayen brought it up. How, really, can bring up those words?

Witness : Suddenly I called him "brother want to come, want to buy a car? Yes, "because I understand their code, I'll just, Mr. Prosecutor.

Prosecutor: So you already know the same thing, that actually the 1 billion money is not realized to buy a car, is it only a code?

Witness : Yes sir prosecutor. 
Question and answer dialogue over the trial of corruption cases in North Sumatra and tried at the Corruption Court in Medan. In the dialog found the code used by the witness to carry out the action. This was confirmed by witnesses and was of particular concern to the Court Clerk. The answers given by witnesses to the questions raised by Judges, Prosecutors, Legal Counsels during the trial. The questions that occurred during the trial in the research [31: pp. 256] question form in the trial in the Surakarta regional court includes four types, namely the usual question sentence, question sentence yes / no, alternative question sentence, and rhetorical question sentence.

Continuation in the trial of the criminal act of corruption has been found clarity in the password answered by the witness. Clarity of interactive dialogue between Judge and Witness previously questioned by the Prosecutor in an open trial. [18: pp. 2] in his paper "Knowing Forensic Linguistics: Linguists as Expert Witnesses" mentioned the involvement of linguists (forensics) in such legal events would certainly be important in the context of law enforcement. With the Judge's question to the Witness for law enforcement, the Judge's question gives the Witness an option. The question can be identified through the dialog below:

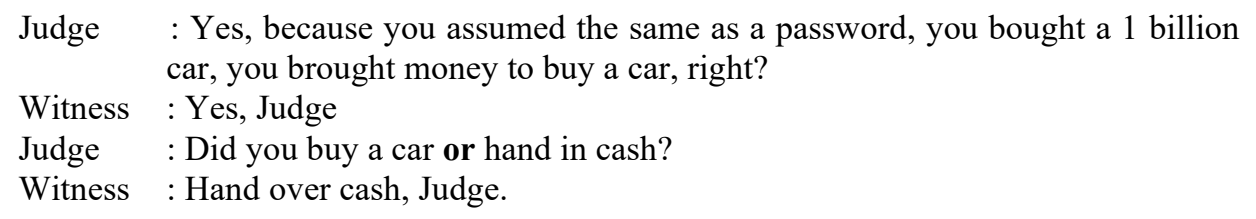

The option given by the Judge is a question that has an answer connected to the previous question. The foresight of the Judge in giving questions is a strategy, so that the trial held finds a common ground. Not just stopping at one point in revealing passwords in corrupt languages. This came again from the Prosecutors who had prepared questions to witnesses to get to the root. Like the dialog below:

Prosecutor: For the Zone, the witness knew that there was a zone written.

Witness : Yes, ahah.

Prosecutor: That witness made it too.

Witness : Yes, I made it.

Prosecutor: Where is it, is it inside?

Witness : On a flash

Prosecutor: Ohhh, on the flash, it's not written, it's not.

Witness : Not on the flash drive ...

Prosecutor : Well, if for egh ... is it related to all the money that has been deposited to witnesses until now there is still left over?

Witness : Nothing ....

Prosecutor : Has everything been submitted?

Witness : Already submitted to the KPK yesterday it was deposited, lastly we paid 300 million to the KPK.

Prosecutor : 300 million

Witness : Yes ...

The discovery of new evidence conducted by the prosecutor in open court is to strengthen the witness statements that the code that is used much more corrupt. This is evident in the dialogue between the prosecutor and the witnesses are new findings that flash words. Their 
common ground is found in open court show a result that is required to dismantle the corruption case hearing speaking patterns.

A good audio recording will make the trial more complete because this will be evidence in the trial. The court that has a sophisticated and modern equipment in the trial will be proportional, so that the completeness of the trial court are met in accordance with international and national standards.

Referring back to the open trial process for the public in corruption cases carried out in the Medan Corruption Court, the court has conducted a list of cases with a total of: 898 cases (Data Update: Sunday, 28 Jul. 2019. 23: 46: 23 WIB)[32]. The high number of cases up to now makes North Sumatra an area of concern in corruption cases. Researcher Indonesian Survey Institute (LSI), Ahmad Khoiril Umam, said that in general the majority of North Sumatra assess the level of corruption to increase in the last two years is $54 \%$ compared with the 2016 survey findings. "So people's perceptions of rising corruption are likely to rise, from $43 \%$ in 2016 to $54 \%$ this year. The perception of North Sumatra residents is relatively the same as public perceptions at the national level," Ahmad Khoiril said in the News Economic News, Wednesday, February 6, 2019.[33]

\section{Conclusion}

"You are smart and we are not stupid", the phrase gives an understanding as smart as possible the squirrel jump will fall too. The code used in corrupt acts is a mutual agreement for common goals and interests in achieving mutual benefit. The most benefit is for them and the loss is aimed at the state and the people who feel that the development program has not been optimal. Taxes from the community are used for fair and equitable development, but what happens is that the quality of the projects implemented is not in line with the hopes and ideals of the community. Plus from print and online media that report about officials who were caught red-handed by the KPK to make people continue to fight against corruption that is increasingly becoming-so. The fight against corruption continues at its root and is expected with scholars, legislators, KPK, officials who are competent to revise the corruption law so that the punishment will be given to corruptors as hard as possible regardless of the background of the corruptor.

Forensic linguistics has its own characteristics in identifying, analyzing, and producing analysis. The working of specific forensic linguistics in the handle case-by-case has a philosophy in micro and macro linguistic study. Especially with the increasingly rampant corruption cases occurred in Indonesia and make a bad image for the Unitary Republic of Indonesia to the nations of the world. Expectations and ideals of the nation Indonesia in realizing the Unitary Republic of Indonesia clean of corruption a serious concern starting from small up to large.

The Papers of Corrupt Language Languages in the Corruption Corruptor Court in the forensic linguistic approach can be continued with other disciplines, so that a new approach will be found in the development of science and knowledge.

\section{ACKNOWLEDGMENT}

Researchers say thank you profusely to the Ministry of Research and Higher Education of the Republic of Indonesia, which has provided the opportunity to follow the Class Doctoral Program at the Universitas Sumatera Utara. Next to the Politeknik Negeri Padang which has given the task of learning to attend lectures at the Universitas Sumatera Utara. The promoters 
and co-promoters who have contributed scientific forensic linguistics, the District Court Corruption in the field and the last on previous research that can not be enumerated in this paper.

\section{References.}

[1] Y. Suwarno dan Et.al, "Strategi Pemberantasan Korupsi," Jakarta, 2006.

[2] P. Jeremy, Strategi Memberantas Korupsi. Jakarta: Transparency International Indonesia, 2008.

[3] Susanto dan D. S. Nanda, "Dimensi Analisis Bahasa Dalam Linguistik Forensik," in Peran Linguistik Forensik Dalam Penegakan Hukum Dan Keadilan Di Indonesia, 2018.

[4] A. Adzkia, "Kepala Sandi Negara Temui Pimpinan KPK Bahas Penyadapan," CNN Indonesia, 2016. [Daring]. Tersedia pada: https://www.cnnindonesia.com/nasional/20160126121731-12-106712/kepala-sandinegara-temui-pimpinan-kpk-bahas-penyadapan.

[5] S. Laluhu, Metamorfosis Sandi Komunikasi Korupsi Yogyakarta. Bandung, 2017.

[6] Komisi Pemberantasan Korupsi (KPK), Kisah korupsi kita: Anatomi Kasus-Kasus Besar dalam Kajian Interdisipliner, 1 ed. Jakarta: KPK, 2017.

[7] T. S. Sinar, "Pemarkah Fungsional dalam Kasus Korupsi," in Peran Linguistik Forensik Dalam Penegakan Hukum Dan Keadilan Di Indonesia, 2018.

[8] Y. Amir Piliang, "Forensik Dalam Persfektif Budaya: Sebuah Tantangan Bagi Semiotika," Jurnal Sosioteknologi, vol. 12, no. 29, hal. 367-376, 2013.

[9] M. Julijanto, "Agama Korupsi dan Negara: Sebuah Analisis Problem Hukum Islam di Indonesia," 2014.

[10] F. Rosarians dan Evans, "10 Kode dan Sandi dalam Kasus-kasus Korupsi," nasional.tempo.co, 2017. [Daring]. Tersedia pada: https://nasional.tempo.co/read/858065/10-kode-dan-sandi-dalam-kasus-kasuskorupsi/full\&view $=$ ok.

[11] E. H. Khasanah, "20 Sandi korupsi di Indonesia ini berhasil diungkap KPK," Brilio.net, 2018. [Daring]. Tersedia pada: https://m.brilio.net/serius/20-sandi-korupsidi-indonesia-ini-berhasil-diungkap-kpk-181105t.html.

[12] R. D. Novianto, "KPK Indentifikasi Penggunaan Sandi Ujian di Kasus Suap Bupati Jepara," nasional.sindonews.com, 2018. [Daring]. Tersedia pada: https://nasional.sindonews.com/read/1360778/13/kpk-indentifikasi-penggunaan-sandiujian-di-kasus-suap-bupati-jepara-1544149917.

[13] F. Agus, "Kode 'Pohon' dan 'Ratu Kecantikan' di Suap Hakim PN Medan,” CNN Indonesia, 2018. [Daring]. Tersedia pada: https://www.cnnindonesia.com/nasional/20180829142743-12-325836/kode-pohondan-ratu-kecantikan-di-suap-hakim-pn-medan.

[14] Adam Prireza, "KPK Ungkap Kode Cheese dalam Kasus Suap Bupati Lampung Tengah," nasional.tempo.co, 2018. [Daring]. Tersedia pada: https://nasional.tempo.co/read/1061291/kpk-ungkap-kode-cheese-dalam-kasus-suapbupati-lampung-tengah.

[15] D. P. Amrih Rahayuningtyas dan D. Setyaningrum, "Pengaruh Tata Kelola dan EGovernment terhadap Korupsi," EKUITAS (Jurnal Ekonomi dan Keuangan), vol. 1, no. 4 , hal. $431,2018$.

[16] U. Hadi, "Negara Dalam Cengkraman Korupsi,” Malang, 2015. 
[17] W. V. Izziyana, "Korupsi Dalam Dimensi Kekuasaan," Jurnal Law Pro Justitia, vol. 1, No. 2, no. Juni, hal. 1-20, 2016.

[18] L. Santoso, D. Meyriswati, dan I. N. Alfian, "Korupsi dan mentalitas: kendala kultural dalam pemberantasan korupsi di Indonesia," Masyarakat, Kebudayaan dan Politik, vol. 27 , no. 4, hal. 159, 2014.

[19] Pusat Bahasa Depdiknas, Kamus Bahasa Indonesia. Jakarta, 2008.

[20] B. Shavers dan J. Bair, Hiding Behind the Keyboard: Uncovering Covert Communication Methods with Forensic Analysis. 2016.

[21] P. S. Angermeyer, Speak English Or What? Code switching And Interpreter Use In New York City Courts. Oxford University Press, 2015.

[22] F. Gunawan, Bahasa Kriptos Para Koruptor, vol. 29, no. 2. 2013.

[23] G. R. McMenamin, Forensic Linguistics Advances in Forensic Stylistics, no. 1. 2002.

[24] M. Coulthard dan A. Johnson, An Introduction To Forensic Linguistics Language In Evidence, 1st ed. New York: Routledge, 2007.

[25] Subyantoro, "Linguistik Forensik : Sumbangsih Kajian Bahasa dalam Penegakan HUKUM," Adil indonesia jurnal, vol. 1, no. 1, hal. 61-70, 2019.

[26] M. Coulthard, A. Johnson, dan D. Wright, An Introduction to Forensic Linguistics: Language in Evidance, 2nd ed. London: Routledge, 2017.

[27] Charlina, "Tindak Tutur Imperatif dalam Bahasa Sidang," Bahas: Jurnal ilmu-ilmu Bahasa dan Sastra, vol. 8, no. 1, hal. 25-32, 2013.

[28] J. Gibbons, Forensic LInguistics: an introduction to language in th justice system. Blackwell: Oxford, 2003.

[29] Sudaryanto, Linguistik, Metode Dan Teknik Analisa Bahasa Pengantar Penelitian Wahana Kebudayaan Secara Linguistik. 2015.

[30] B. Bungin, Penelitian Kualitatif: Komunikasi, Ekonomi, Kebijakan Publik, Dan Ilmu Sosial Lainnya. Jakarta: Prenada Media, 2011.

[31] D. Purnanto, H. Yustanto, dan M. Nugroho, "Bentuk dan fungsi tanya jawab dalam persidangan pidana dalam pengadilan wilayah Surakarta," Surakarta, 2013.

[32] Mahkamah Agung Republik Indonesia, "Sistem Informasi Penelusuran Perkara: Pengadilan Negeri Medan,” 2015. [Daring]. Tersedia pada: http://sipp.pnmedankota.go.id/.

[33] K. Lubis, "Di Sumut, Kasus Korupsi Terbanyak dari Sektor Infrastruktur," wartaekonomi.co.id, 2019. [Daring]. Tersedia pada: https://www.wartaekonomi.co.id/read214548/di-sumut-kasus-korupsi-terbanyak-darisektor-infrastruktur.html. 
